\section{Biochemical changes and physiological quality of corn seeds subjected to different chemical treatments and storage times}

\author{
Thiago Lucas de Oliveira ${ }^{1 *}$ (D), Renzo Garcia Von Pinho ${ }^{1}$ (D) Heloisa Oliveira \\ dos Santos ${ }^{1}$, Karen Marcelle de Jesus Silva ${ }^{2}$, Elise de Matos Pereira ${ }^{1}$ (D), \\ João Lucas Dias Souza ${ }^{1}$ iD
}

\begin{abstract}
The chemical treatment of corn seeds is widely adopted for protecting crops at the early stages. However, some molecules interfere in the quality of seeds, especially when stored, by accelerating their deterioration. The objective of this work was to investigate the influence of insecticides on the enzymatic expression and quality of corn seeds subjected to storage. Seeds of the hybrids 2B647PW and SHS4070 were subjected to four different chemical treatments (standard treatment, standard + clothianidin, standard + thiamethoxam, and standard + fipronil) and stored for different periods (0, 3, 6, and 9 months). The quality evaluation included the germination test, first germination count, cold test, and health test. The expression of the enzymes $\alpha$-amylase, esterase, superoxide dismutase, catalase, and alcohol dehydrogenase were determined by the gel electrophoresis technique. The insecticides clothianidin, thiamethoxam, and fipronil reduce the physiological quality of the seeds of hybrid 2B647PW after nine months of storage. The treatment of seeds with the insecticides clothianidin, thiamethoxam, and fipronil reduces the expression of $\alpha$-amylase, superoxide dismutase, and catalase enzymes after nine months of storage. The enzymes $\alpha$-amylase, superoxide dismutase, catalase, and alcohol dehydrogenase are good quality markers for hybrid corn seeds.
\end{abstract}

Index terms: Zea mays L., seed treatment, enzymes, deterioration.

\section{Alterações bioquímicas e qualidade fisiológica de sementes de milho submetidas a diferentes tratamentos químicos e tempos de armazenamento}

RESUMO: O tratamento químico de sementes de milho é prática amplamente adotada para proteção das lavouras. No entanto, algumas moléculas interferem na qualidade das sementes, sobretudo quando armazenadas, acelerando sua deterioração. $O$ objetivo deste trabalho foi investigar a influência de inseticidas sobre a expressão enzimática e qualidade de sementes de milho submetidas ao armazenamento. Sementes dos híbridos 2B647PW e SHS4070 foram submetidas a quatro diferentes tratamentos químicos (tratamento padrão, padrão + clotianidina, padrão + tiametoxam e padrão + fipronil) e armazenadas por diferentes períodos $(0,3,6$ e 9 meses). Os testes de qualidade incluíram a primeira contagem de germinação, germinação, teste frio sem solo e teste de sanidade. A expressão das enzimas $\alpha$-amilase, esterase, superóxido dismutase, catalase e álcool desidrogenase foram determinadas pela técnica de eletroforese em gel. Concluiu-se que os inseticidas clotianidina, tiametoxam e fipronil reduzem a qualidade fisiológica das sementes do híbrido 2B647PW aos nove meses de armazenamento. $O$ tratamento das sementes com os inseticidas clotianidina, tiametoxam e fipronil reduz a expressão das enzimas $\alpha$-amilase, superóxido dismutase e catalase aos nove meses de armazenamento. As enzimas $\alpha$-amilase, superóxido dismutase, catalase e álcool desidrogenase são bons marcadores da qualidade de sementes híbridas de milho.

Termos para indexação: Zea mays L., tratamento de sementes, enzimas, deterioração.
Journal of Seed Science, v.42, e202042038, 2020

http://dx.doi.org/10.1590/ 2317-1545v42234181
$*$ Corresponding author E-mail: thiagolucas.agro@gmail.com

Received: $2 / 18 / 2020$. Accepted: 9/9/2020.

${ }^{1}$ Departamento de Agricultura, Universidade Federal de Lavras, Caixa Postal 3037, 37200-900 Lavras, MG, Brasil.

${ }^{2}$ Instituto Federal do Norte de Minas, 39480-000 - Campus Januária, Januária, MG, Brasil. 


\section{INTRODUCTION}

Corn (Zea mays L.) is one of the most important grain crops worldwide, and Brazil places third in volume of production (CONAB, 2020). This prominent position results from technological advances over the years, including enhancing crop management techniques, the development of genetically superior hybrids, and the use of good quality seeds.

Modern corn seeds are the product of many years of research and development, and they carry technological innovations that might translate into a great production. To assure the fulfillment of this enormous potential, it is necessary not only to use high-quality seeds but also to adopt measures that safeguard this quality, such as effective seed treatments. The usual treatments aim to protect seeds against pests and pathogens by using insecticide and fungicide molecules (Menten and Moraes, 2010).

Some molecules used in chemical treatments influence the viability of stored seeds, accelerating their spoilage (Deuner et al., 2014; Tonin et al., 2014). In these cases, the progression of the deterioration process is a consequence of oxidative stress caused by the intense production and accumulation of reactive oxygen species (ROS) in the cells. The augment in ROS production is a response of the plant tissues to their exposure to foreign molecules, such as insecticides (Bashir et al., 2007; Shakir et al., 2018).

ROS are reduced chemical forms, energetically more reactive than the molecular oxygen, produced continuously in the cells (Sies et al., 2017). These radicals or molecules play a crucial role in plant growth and development, as they act as signals that regulate and contribute to maintaining cell physiological functions to a normal (Huang et al., 2016; Mittler, 2017). To keep ROS at non-toxic levels, cells have antioxidant mechanisms, composed of enzymatic and non-enzymatic systems that either degrade or convert these compounds when they surpass certain thresholds. If these antioxidant mechanisms fail to contain the excess of these products, there is the possibility of damaging the cell apparatus, thus compromising structures and the function of organelles and macromolecules, such as proteins and DNA (Sharma et al., 2012).

Some antioxidant enzymes, like superoxide dismutase (SOD) and catalase (CAT), are boosted when the plant is exposed to insecticides (Yücel et al., 2018). This phenomenon is an attempt to remove the overabundant ROS (namely, superoxide radical and hydrogen peroxide). When the antioxidant defense mechanisms fail to prevent the excessive formation of free radicals, the enzyme activity and overall plant metabolism tend to decrease due to structural damages (Bashir et al., 2007). Consequently, the viability of the seed reduces, and so does its germination and vigor (Coskun et al., 2015). In this sense, analyses of superoxide dismutase and catalase have been often employed in several studies as complementary tools for determining the quality of corn seeds, once their activity changes as seed deterioration progresses (Timóteo and Marcos-Filho, 2013; Galvão et al., 2014; Ferreira et al., 2015; Heberle et al., 2019).

Similarly, enzymes regulating reserve degradation or cellular respiration have also been deemed important markers in seed quality studies. The increased expression of $\alpha$-amylase in corn, for example, is linked to higher vigor and better seed germination rates (Oliveira et al., 2013; Lopes et al., 2017). In turn, alcohol dehydrogenase (ADH), an enzyme involved in anaerobic respiration, prevents the buildup of acetaldehyde, a compound toxic to cells. In this sense, the more intense enzyme production can contribute to preserving seed quality (Caixeta et al., 2014; Carvalho et al., 2014). In addition to these enzymes, esterases, which are responsible for lipid metabolism and membrane degradation, were also evaluated in deterioration research (Ferreira et al., 2015).

However, despite the relatively numerous works relating enzymes to seed quality, only a few of them approach the enzymatic activity in insecticide-treated seeds. These analyses can be valuable instruments for understanding the biochemical mechanisms behind some phytotoxicity to corn seeds due to exposure to chemical molecules.

Performing health tests when seeds undergo treatment is also paramount not only to understand the effect of chemical molecules in reducing the pathogen load but also to check the impact of these compounds on the physiological response of the plant. In some cases, the enzymatic expression and seed health must be assessed together, as some fungus species produce enzymes also present in metabolic pathways of the plant, which might lead to inconsistent results (Silva et al., 2000). 
On that account, this study aimed to investigate the influence of insecticide treatments on the physiological quality and health of corn seeds. The enzymatic expression when the seeds undergo storage was withal evaluated.

\section{MATERIAL AND METHODS}

The experiment was conducted in the Department of Agriculture of the Federal University of Lavras (Universidade Federal de Lavras, UFLA) - specifically, the enzymatic and physiological quality analyzes were carried out at the Central Laboratory for Seed Analysis of the institution. The tests used corn seeds from single lots of the simple hybrid 2B647PW and double hybrid SHS4070. They had been produced during the winter, in Paracatu, and processed in Patos de Minas, both cities located in the Brazilian state of Minas Gerais.

The seeds were subjected to different chemical treatments and storage times. In all cases, they were first treated with the standard mixture provided by the seed-trading company, composed of $17 \%$ of carbendazim + thiram (Derosal Plus $^{\circledR}$ ), $1 \%$ of deltamethrin $\left(\right.$ Actellic $^{\circledR}$ ), $1 \%$ of pirimiphos-methyl (K-obiol ${ }^{\circledR}$ ), and $81 \%$ of water.

The trials comprised one control (treated only with the standard mixture) and experimental groups in which the insecticides clothianidin (Poncho ${ }^{\circledR}$ ), thiamethoxam (Cruiser ${ }^{\circledR} 350 \mathrm{FS}$ ), and fipronil (Shelter ${ }^{\circledR}$ ) were added to the standard mixture. The insecticide doses complied with the recommendations of their manufacturers. The seed treatment was performed manually, inside plastic bags, so as to distribute the mixture evenly. The details are described in Table 1.

After the treatment, the seeds were packed in semipermeable, multi-layered paper bags, which were placed on wooden pallets and kept in a non-controlled environment (conventional warehouse). The seeds were stored for four different times $(0,3,6$, and 9 months). The climatic environment conditions were monitored throughout these periods and scored averages of $23{ }^{\circ} \mathrm{C}$ and $62 \%$ relative humidity. During the entire storage, the seeds had their moisture measured, and no variations were observed.

The physiological quality of the seeds was assessed after each storage period $(0,3,6$, and 9 months). For the germination testing, four replications of 50 seeds were sown on paper towel rolls (moistened at 2.5 times their dry weight), which were kept inside a germinator at $25^{\circ} \mathrm{C}$ and under constant lighting. The germination test was performed on the seventh day after sowing, and the first germination was counted on the fourth day. The results were expressed in terms of percentage of normal seedlings (Brasil, 2009a).

The cold test without soil was conducted with four replications of 50 seeds, on paper towels moistened with water at 2.5 times the dry paper weight. The rolls were packed in plastic bags and kept in a cold chamber at $10^{\circ} \mathrm{C}$ for seven days. After that, they were taken out from the plastic bags and placed in a germinator set at $25^{\circ} \mathrm{C}$, under constant light, for four days (Barros, 1999). Ultimately, the evaluation considered the normal seedlings only, according to the criteria adopted for the germination test.

Seed health was assessed via incubation on a paper substrate (blotter test), following the methodology proposed in the Manual for Seed Health Analysis (Manual de Análise Sanitária de Sementes) (Brasil, 2009b). In this case, eight replications of 50 seeds were used per treatment. These seed sets were placed onto three previously sterilized and moistened filter-paper sheets lying inside transparent Petri dishes with a lid. The samples were cooled down in a

Table 1. Composition of the experimental chemical treatments and details on the insecticides.

\begin{tabular}{cccc}
\hline $\begin{array}{c}\text { Treatment } \\
\text { identification }\end{array}$ & Treatment composition & $\begin{array}{c}\text { Dose of the active principle } \\
\text { (g ap/100 kg of seeds) }\end{array}$ & $\begin{array}{c}\text { Active principle in the } \\
\text { commercial product }\end{array}$ \\
\hline S & Standard mixture & - & - \\
SC & Standard mixture + Clothianidin & 210 & $60 \%$ \\
ST & Standard mixture + Thiamethoxam & 210 & $35 \%$ \\
SF & Standard mixture + Fipronil & 62.5 & $25 \%$ \\
\hline
\end{tabular}


freezer for $24 \mathrm{~h}$ and then incubated at $20 \pm 2{ }^{\circ} \mathrm{C}$ for ten days, under a 12-hour photoperiod. After that, the seeds were examined individually with a stereomicroscope, in order to check for any fructification typical of fungal growth. The results were delivered in percentage of fungus occurrence.

The enzymes $\alpha$-amylase (EC 3.2.1.1), catalase (EC 1.11.1.6), superoxide dismutase (EC 1.15.1.1), alcohol dehydrogenase (EC 1.1.1.1), and esterase (EC 3.1.1) had their expression appraised via the electrophoresis technique. For these analyses, 100-gram samples of whole and dried seeds (except for $\alpha$-amylase) from each treatment were ground with PVP and liquid nitrogen and then stored at $-86^{\circ} \mathrm{C}$. The extraction of the enzymes used the buffer Tris- $\mathrm{HCl}$ $0.2 \mathrm{M} \mathrm{pH} 8.0+0.1 \% \beta$-mercaptoethanol, at $250 \mu \mathrm{L}$ per $100 \mathrm{mg}$ of seeds. The material was vortexed and kept overnight inside a refrigerator. After that, they were centrifuged at $14,000 \mathrm{rpm}$ for 60 minutes at $4{ }^{\circ} \mathrm{C}$.

Before the $\alpha$-amylase extraction, the seeds were pre-germinated on a paper roll for 70 hours. Then, roots and plumules were discarded, and the remaining parts were crushed with the antioxidant PVP and liquid nitrogen. The extraction used $200 \mathrm{mg}$ of the germinated-seed macerate mixed with $600 \mu \mathrm{L}$ of the extraction buffer (Tris- $\mathrm{HCl} 0.2 \mathrm{M} \mathrm{pH} \mathrm{8.0} \mathrm{+0.4 \%} \mathrm{PVP).}$

The electrophoretic runs employed $7.5 \%$ and $4.5 \%$ polyacrylamide gels for separation and concentration, respectively - for $\alpha$-amylase, $0.5 \%$ starch was added. The gel-electrode system used the buffer Tris-glycine $\mathrm{pH}$ 8.9. A volume of $50 \mu \mathrm{L}$ of the sample supernatant was poured onto the gel, and the electrophoretic run was performed at $150 \mathrm{~V}$ for 6 hours. The gels were developed for each enzyme, following the methodologies proposed by Alfenas (2006).

The experiment followed a completely randomized design, with a triple factorial scheme 2 (hybrid types) $x 4$ (chemical treatments) $\times 4$ (storage times). The data on the physiological quality and health of the seeds were submitted to the analysis of variance, and the means were compared by the Tukey test at a $5 \%$ probability level. The statistical analyses were handled by the software Sisvar (Ferreira, 2011). The enzymatic expression was interpreted based on the qualitative analysis of the electrophoresis gels, taking into account the presence/absence of each band and their intensity.

\section{RESULTS AND DISCUSSION}

A triple interaction among the factors hybrid type, storage time, and chemical treatment was observed in the variables germination (G), first germination count (FGC), and cold test without soil (CT) (Table 2).

Table 2. Summary of the analysis of variance of the physiological quality parameters measured in seeds of the corn hybrids 2B647PW and SHS4070 subjected to different chemical treatments and storage times.

\begin{tabular}{ccrcr}
\hline \multirow{2}{*}{ VF } & DF & \multicolumn{3}{c}{ Mean square } \\
\cline { 3 - 4 } & & \multicolumn{1}{c}{$\mathrm{G}^{1}$} & $\mathrm{FGC}$ & $\mathrm{CT}$ \\
\hline HYBRID & 1 & $422.92^{* *}$ & $1835.17^{* *}$ & $3923.50^{* *}$ \\
TIME & 3 & $139.36^{* *}$ & $6534.42^{* *}$ & $502.54^{* *}$ \\
TREATMENT & 3 & $3.82^{\mathrm{NS}}$ & $825.29^{* *}$ & $207.37^{* *}$ \\
H x TIME & 3 & $100.58^{* *}$ & $207.02^{* *}$ & $468.77^{* *}$ \\
H x TREAT & 3 & $5.60^{\text {NS }}$ & $119.86^{* *}$ & $153.58^{* *}$ \\
TIME x TREAT & 9 & $10.07^{*}$ & $304.39^{* *}$ & $103.24^{* *}$ \\
H x TIME x TREAT & 9 & $9.48^{*}$ & $238.48^{* *}$ & $87.53^{* *}$ \\
Error & 96 & 4.51 & 19.03 & 12.08 \\
\hline Total & 127 & & & 91.06 \\
Mean & & 96.43 & 85.56 & 3.82 \\
CV (\%) & & 2.20 & 5.10 & \\
\hline
\end{tabular}

${ }^{1} \mathrm{G}$ : final germination; FGC: first germination count; $\mathrm{CT}$ : cold test without soil.

**significant at a $1 \%$ probability level; * significant at a $5 \%$ probability level, Ns non-significant; according to the $\mathrm{F}$ test. 
In general, the seeds of hybrid 2B647PW had their germination reduced during storage. Moreover, the ones treated with clothianidin and fipronil differed from the control treatment and exhibited the lowest germination values after nine months (Table 3). The negative influence of fipronil on the physiological quality and development of corn seedlings is not a novelty. The compound was linked to low germination percentages and less seedling growth in an experiment that tested different insecticides for corn seed treatment (Espíndola et al., 2018). It is worth mentioning that, even in the most harmful treatments, the germination still scored above the minimum allowed for corn seed commercialization in Brazil (85\%) (Brasil, 2013).

Supporting the findings of the present study, others also reported that insecticides added to seeds can cause unfavorable latent effects to their quality, which tend to escalate as the storage time extends (Lorenzetti et al., 2014). Besides, the damages get more intense once the defense mechanisms of the plant become faulty (Bashir et al., 2007).

The germination behavior of the hybrid SHS4070 showed no significant alteration, with values similar to those attained at the beginning of storage. In their research, Tonin et al. (2014) also concluded that the quality of corn seeds treated with insecticide and stored was affected not only by the chemicals applied and storage conditions but also by the hybrid type.

According to the first germination count, seed germination declined with warehousing, and the lowest values were observed up from the sixth month (Table 4). Similar changes were reported in other studies, with reductions in germination after four months of storage (Deuner et al., 2014).

Seeds of the hybrid 2B647PW treated with thiamethoxam (ST) differed from the others and exhibited lower first germination counts after three months of storage. An analogous reduction was noticed in the hybrid SHS4070 after six months of warehousing (Table 4). Some studies proved the deleterious effect of thiamethoxam on seeds stored for long periods (Deuner et al., 2014; Tonin et al., 2014).

By the ninth month of storage, the treatment with clothianidin (SC) was much similar to the one with thiamethoxam, both with the lowest germination rates in the corresponding period. The non-ionic character of these molecules allows them to trespass the corn seed semipermeable membranes, thus facilitating their contact with the embryo and enabling toxic effects (Dias et al., 2014; Baldini et al., 2018).

The first germination count of the treatments with fipronil (SF) on seeds of the hybrids 2B647PW and SHS4070 did not differ from the control throughout storage. As the storage extends, a sharper decline in the physiological quality of seeds is expected, since the advanced deterioration implies less efficiency and less activity of the enzymatic systems, and also membrane destabilization due to oxidative stress (Timóteo and Marcos-Filho, 2013).

Table 3. Germination (G, \%) of seeds of the corn hybrids 2B647PW and SHS4070 subjected to different chemical treatments and storage times.

\begin{tabular}{|c|c|c|c|c|c|}
\hline \multirow{2}{*}{ Hybrid } & \multirow{2}{*}{ Treatment } & \multicolumn{4}{|c|}{ Storage time (months) } \\
\hline & & 0 & 3 & 6 & 9 \\
\hline \multirow{4}{*}{ 2B647PW } & $S^{1}$ & $97 \mathrm{aA}$ & $95 \mathrm{abA}$ & $92 \mathrm{bA}$ & $94 \mathrm{abA}$ \\
\hline & SC & 99 aA & 97 aA & $92 \mathrm{bA}$ & $86 \mathrm{cC}$ \\
\hline & ST & $98 \mathrm{aA}$ & $98 \mathrm{aA}$ & $93 \mathrm{bA}$ & $91 \mathrm{bAB}$ \\
\hline & SF & $99 \mathrm{aA}$ & $97 \mathrm{abA}$ & $95 \mathrm{bA}$ & $89 \mathrm{cBC}$ \\
\hline \multirow{4}{*}{ SHS4070 } & $S$ & $100 \mathrm{aA}$ & $98 \mathrm{aA}$ & $98 \mathrm{aA}$ & $98 \mathrm{aA}$ \\
\hline & SC & $99 \mathrm{aA}$ & $98 \mathrm{aA}$ & $98 \mathrm{aA}$ & $98 \mathrm{aA}$ \\
\hline & ST & $97 \mathrm{aA}$ & $98 \mathrm{aA}$ & $98 \mathrm{aA}$ & $98 \mathrm{aA}$ \\
\hline & SF & $100 \mathrm{aA}$ & $98 \mathrm{aA}$ & $98 \mathrm{aA}$ & $98 \mathrm{aA}$ \\
\hline
\end{tabular}

Means followed by the same uppercase letter (column) or lowercase letter (row), within each hybrid type, do not differ according to the Tukey test at a $5 \%$ significance.

${ }^{1} \mathrm{~S}$ : standard treatment; SC: standard treatment + clothianidin; ST: standard treatment + thiamethoxam; SF: standard treatment + fipronil. 
Table 4. First germination count (FGC, \%) of seeds of the corn hybrids 2B647PW and SHS4070 subjected to different chemical treatments and storage times.

\begin{tabular}{|c|c|c|c|c|c|}
\hline \multirow{2}{*}{ Hybrid } & \multirow{2}{*}{ Treatment } & \multicolumn{4}{|c|}{ Storage time (months) } \\
\hline & & 0 & 3 & 6 & 9 \\
\hline \multirow{4}{*}{ 2B647PW } & $S^{1}$ & $97 \mathrm{aA}$ & $87 \mathrm{bA}$ & $60 \mathrm{cA}$ & $90 \mathrm{abA}$ \\
\hline & $\mathrm{SC}$ & $99 \mathrm{aA}$ & $91 \mathrm{aA}$ & $67 \mathrm{bA}$ & $71 \mathrm{bc}$ \\
\hline & ST & $98 \mathrm{aA}$ & $81 \mathrm{bB}$ & $51 \mathrm{cB}$ & $78 \mathrm{bBC}$ \\
\hline & SF & $99 \mathrm{aA}$ & $93 \mathrm{aA}$ & $61 \mathrm{cA}$ & $83 \mathrm{bAB}$ \\
\hline \multirow{4}{*}{ SHS4070 } & $\mathrm{S}$ & $99 \mathrm{aA}$ & $99 \mathrm{aA}$ & 87 bA & $93 \mathrm{abA}$ \\
\hline & $\mathrm{SC}$ & $98 \mathrm{aA}$ & $94 \mathrm{aA}$ & $70 \mathrm{bB}$ & $91 \mathrm{aA}$ \\
\hline & ST & $97 \mathrm{aA}$ & $94 \mathrm{abA}$ & $40 \mathrm{cC}$ & $88 \mathrm{bA}$ \\
\hline & SF & $99 \mathrm{aA}$ & $96 \mathrm{aA}$ & $87 \mathrm{bA}$ & $94 \mathrm{abA}$ \\
\hline
\end{tabular}

Means followed by the same uppercase letter (column) or lowercase letter (row), within each hybrid type, do not differ according to the Tukey test at a $5 \%$ significance.

${ }^{1} \mathrm{~S}$ : standard treatment; SC: standard treatment + clothianidin; ST: standard treatment + thiamethoxam; SF: standard treatment + fipronil.

Changes in the vigor of the hybrid 2B647PW seeds were also detected by the cold test (CT) (Table 5). As in the first germination count, the lowest averages were found after six months of storage. According to the cold test, the hybrid SHS4070 did not show significant differences regarding germination. Some studies confirmed the efficiency of this testing for assessing the variations in the level of vigor of corn seeds (Tonin et al., 2014; Baldini et al., 2018).

The fungicides within the standard mixture did not entirely inhibit the fungus growth in the hybrid seeds (Table 6). However, fungal proliferation reduced considerably throughout storage, which signalizes the efficacy of the treatment in preventing those organisms. Also, the insecticides added to the mixture did not influence the efficiency of the fungicides.

A high incidence of microorganisms was noticed in the seeds during the first three months of storage - remarkably Fusarium spp., whose incidence reached $97.5 \%$. Fusarium spp. is a fungus genus that grows fast and aggressively, affecting the quality of seeds and even causing their death before germination (Menten, 1995). Despite being

Table 5. Cold test without soil (CT, \%) performed in corn seeds of the hybrids 2B647PW and SHS4070 subjected to different chemical treatments and storage times.

\begin{tabular}{cccccc}
\hline \multirow{2}{*}{ Hybrid } & Treatment & \multicolumn{4}{c}{ Storage time (months) } \\
\cline { 3 - 5 } & & 0 & 3 & 6 & 9 \\
\hline \multirow{3}{*}{2 S647PW } & $93 \mathrm{aA}$ & $95 \mathrm{aA}$ & $89 \mathrm{aA}$ & $82 \mathrm{bB}$ \\
& SC & $95 \mathrm{aA}$ & $86 \mathrm{bB}$ & $79 \mathrm{cB}$ & $95 \mathrm{aA}$ \\
& $\mathrm{ST}$ & $95 \mathrm{aA}$ & $89 \mathrm{aAB}$ & $70 \mathrm{bC}$ & $75 \mathrm{bC}$ \\
& SF & $92 \mathrm{aA}$ & $91 \mathrm{aAB}$ & $73 \mathrm{bBC}$ & $67 \mathrm{bD}$ \\
\hline \multirow{3}{*}{ SHS4070 } & S & $97 \mathrm{aA}$ & $97 \mathrm{aA}$ & $95 \mathrm{aA}$ & $96 \mathrm{aA}$ \\
& SC & $99 \mathrm{aA}$ & $94 \mathrm{aA}$ & $97 \mathrm{aA}$ & $98 \mathrm{aA}$ \\
& ST & $99 \mathrm{aA}$ & $98 \mathrm{aA}$ & $97 \mathrm{aA}$ & $98 \mathrm{aA}$ \\
& SF & $94 \mathrm{aA}$ & $93 \mathrm{aA}$ & $95 \mathrm{aA}$ & $95 \mathrm{aA}$ \\
\hline
\end{tabular}

Means followed by the same uppercase letter (column) or lowercase letter (row), within each hybrid type, do not differ according to the Tukey test at a $5 \%$ significance.

${ }^{1} \mathrm{~S}$ : standard treatment; SC: standard treatment + clothianidin; ST: standard treatment + thiamethoxam; SF: standard treatment + fipronil. 
Table 6. Average incidence (\%) of fungi in seeds of the corn hybrids 2B647PW (H1) and SHS4070 (H2) subjected to different chemical treatments and storage times.

\begin{tabular}{|c|c|c|c|c|c|c|c|}
\hline \multirow{3}{*}{$\begin{array}{l}\text { Storage time } \\
\text { (months) }\end{array}$} & \multirow{3}{*}{ Treatment } & \multicolumn{6}{|c|}{ Fungus (\%) } \\
\hline & & \multicolumn{2}{|c|}{ Fusarium spp. } & \multicolumn{2}{|c|}{ Penicillium spp. } & \multicolumn{2}{|c|}{ Aspergillus spp. } \\
\hline & & $\mathrm{H} 1$ & $\mathrm{H} 2$ & $\mathrm{H} 1$ & $\mathrm{H} 2$ & $\mathrm{H} 1$ & $\mathrm{H} 2$ \\
\hline \multirow{4}{*}{0} & $S^{1}$ & 71.5 & 56.5 & 21.0 & 19.5 & 3.5 & 11.0 \\
\hline & SC & 57.0 & 53.5 & 17.5 & 5.5 & 1.0 & 20.0 \\
\hline & ST & 44.5 & 29.0 & 12.0 & 7.5 & 1.0 & 22.5 \\
\hline & SF & 42.0 & 54.0 & 25.0 & 13.0 & 4.5 & 19.5 \\
\hline \multirow{4}{*}{3} & $S$ & 95.0 & 23.5 & 28.0 & 15.0 & 2.5 & 28.5 \\
\hline & SC & 86.0 & 13.0 & 41.0 & 12.0 & 1.5 & 17.0 \\
\hline & ST & 78.0 & 15.0 & 23.0 & 11.5 & 4.0 & 24.5 \\
\hline & SF & 97.5 & 97.0 & 88.0 & 46.0 & 4.0 & 19.0 \\
\hline \multirow{4}{*}{6} & $S$ & 0.5 & 0.0 & 6.0 & 8.5 & 8.0 & 5.0 \\
\hline & SC & 0.0 & 0.0 & 0.0 & 6.0 & 6.0 & 10.0 \\
\hline & ST & 0.0 & 0.0 & 5.0 & 11.5 & 2.5 & 15.0 \\
\hline & SF & 0.0 & 0.0 & 6.5 & 1.0 & 2.5 & 9.5 \\
\hline \multirow{4}{*}{9} & $S$ & 0.0 & 0.0 & 1.5 & 0.5 & 2.5 & 7.0 \\
\hline & SC & 0.5 & 0.0 & 0.0 & 0.5 & 0.0 & 2.5 \\
\hline & ST & 0.0 & 0.0 & 0.0 & 0.0 & 0.5 & 8.0 \\
\hline & SF & 2.0 & 0.0 & 0.0 & 2.0 & 0.0 & 11.5 \\
\hline
\end{tabular}

'S: standard treatment; SC: standard treatment + clothianidin; ST: standard treatment + thiamethoxam; SF: standard treatment + fipronil.

transmitted to the seeds, they are considered field fungi and can compromise the plant stand formation by affecting the germination and development of seedlings (Kuhnem-Júnior et al., 2013). In corn seeds, the increasing incidence of Fusarium spp. was reported up to the sixth month of storage (Antonello et al., 2009).

Considering the three months, the incidence of Aspergillus spp. and Penicillium spp. also augmented. These fungi are typical of storage and act as deterioration indicators, as they can cause changes in the chemical composition and loss of dry matter of stored products (Stefanello et al., 2015). In this work, the fungi Penicillium spp. and Aspergillus spp. lingered longer in the seeds than Fusarium spp. This incidence variation occurred precisely because the two firsts are storage-related fungi, thus being able to survive and develop under warehousing conditions.

Regarding the effect of post-treatment storage on corn seeds, the hybrid 2B647PW produced less $\alpha$-amylase after nine months of storage. In this case, the lowest expression corresponded to the insecticide-added treatments (Figure 1). This enzyme is responsible for hydrolyzing starch in the endosperm, releasing the energy required by processes such as germination. The reduction in its expression by the ninth month of storage is consistent with the results of germination and vigor obtained for the same period, as the aforementioned hybrid yielded seeds of inferior quality (Tables 3 and 4). On the other hand, the expression of this enzyme by the hybrid SHS4070 remained stable throughout the storage, reinforcing the germination and cold test data, which showed no significant differences.

Research correlated the sub-expression of $\alpha$-amylase to the low quality of corn seeds, proving that this enzyme is directly linked to the physiological potential of the grains (Oliveira et al., 2013; Timóteo and Marcos-Filho, 2013). As the deterioration progresses, the aleurone layer suffers alterations that cause the $\alpha$-amylase synthesis to decrease (Ganguli and Senmandi, 1993). As a result, the amylolytic activity is expected to decline, leading to a reduction in the germination capacity of the seeds. 


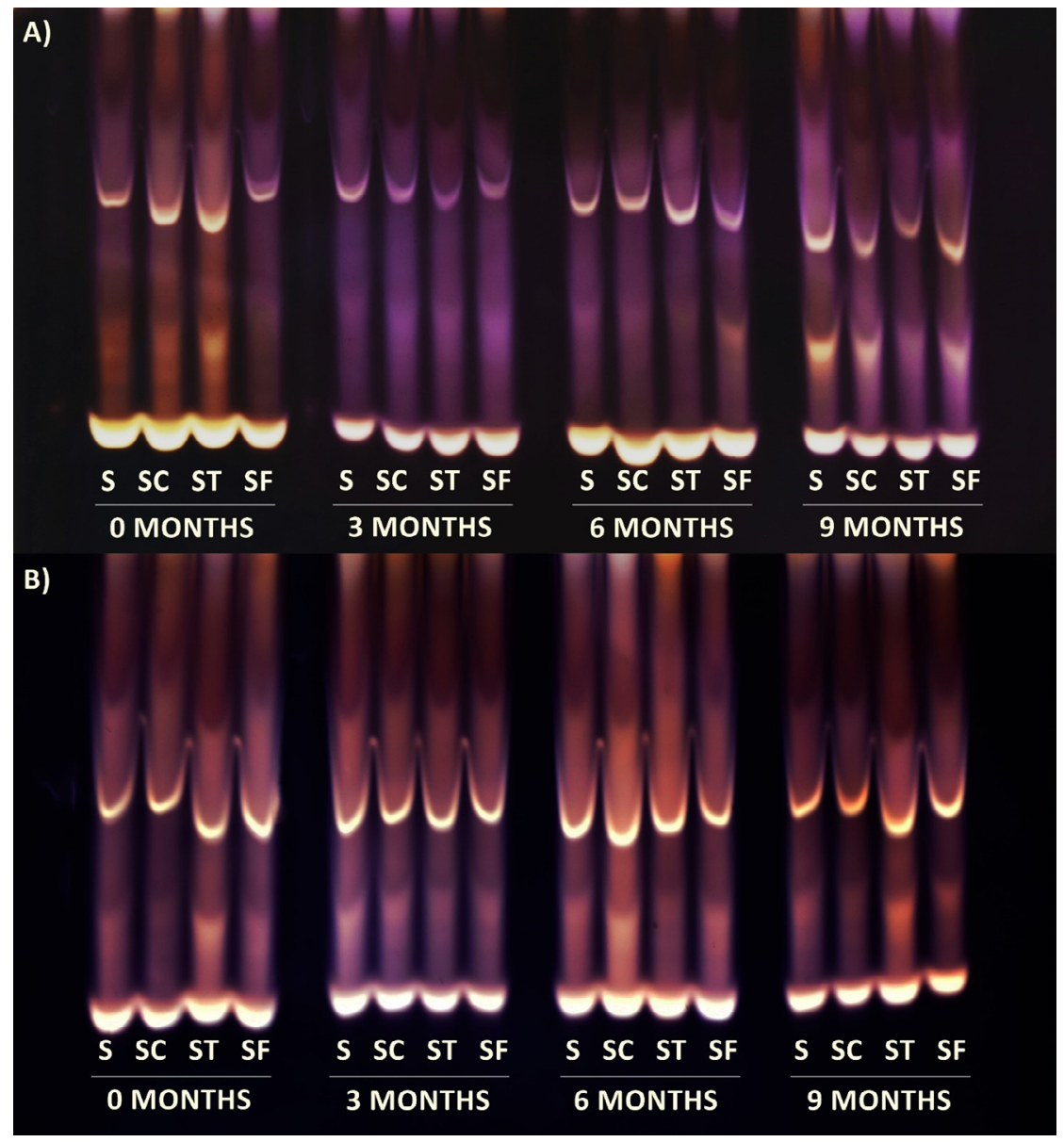

S: standard treatment; SC: standard + clothianidin; ST: standard + thiamethoxam; SF: standard + fipronil.

Figure 1. Alpha-amylase expression in seeds of the hybrids 2B647PW (A) and SHS4070 (B) treated with different products and stored for different times $(0,3,6$, and 9 months).

In general, the expression of esterase did not change in any of the hybrids under study (Figure 2). Although an increased production of esterase was reported in corn seeds in an advanced state of deterioration (Ferreira et al., 2015), significant changes in its expression behavior are more likely in seeds with high lipid content, as the enzyme participates in ester hydrolysis and lipid metabolism (Carvalho et al., 2014). The relationship of esterase with the deterioration of seeds is explained by its action on the lipid layers, causing membrane destabilization, and contributing to the deteriorative process (Vieira et al., 2006).

Regarding the hybrid 2B647PW, the expression of superoxide dismutase and catalase augmented at the beginning of storage in those treatments added of insecticides (Figures $3 \mathrm{~A}$ and $4 \mathrm{~A}$ ). Both enzymes are related to oxidative stress and act by protecting the cells against reactive oxygen species (Sharma et al., 2012). The production of these enzymes remained high up to the sixth month of storage, a phenomenon that can be interpreted as a cell attempt to defend themselves against free radicals and other molecules formed due to insecticide exposure and physiological deterioration. When subjected to insecticides, plant tissues can respond by boosting the production of hydrogen peroxide and other reactive oxygen species (Bashir et al., 2007; Shakir et al., 2018).

After nine months, the expression of enzymes diminished, which might be a consequence of the advanced deterioration of the seeds. When the protection systems of the plant are no longer able to prevent the formation and action of toxic compounds, it is common to observe a decrease in enzymatic activity and inactivation of enzymes due to structural damages (Bashir et al., 2007). This behavior is supported by literature that reports low expression and 
activity of catalase and superoxide dismutase at advanced deterioration states (Abreu et al., 2013; Heberle et al., 2019). The exposure of plant tissues to the insecticides deltamethrin, imidacloprid, and chlorpyrifos also reduces the catalase activity, thus evidencing the oxidative stress generated by these molecules (Bashir et al., 2007; Parween et al., 2012; Sharma et al., 2013).

The resulting electrophoretic patterns reaffirmed the physiological quality tests of the hybrid 2B647PW. They suggested that the reduced enzymatic expression is linked to the deterioration of the seeds, which translated into low germination and less vigor. As for the hybrid SHS4070, the electrophoresis outcome contradicted the germination and cold test results, in which the hybrid had a steady behavior throughout storage.

This fact can be explained by the sequence of events that characterize seed deterioration. In this process, biochemical alterations, such as oxidative stress, damages to molecules and the membrane system, consumption of reserves, low enzymatic activity, and variations in the respiratory rate of the seeds, precede their loss of germination potential and vigor (Marini et al., 2013, Ebone et al., 2019; Kurek et al., 2019).

Therefore, assessing the enzymatic changes can be more effective in gauging the deterioration status of seeds than traditional physiological quality tests (Spinola et al., 2000). The greater sensitivity to deterioration makes these enzymes suitable molecular markers to monitor and characterize seed quality.

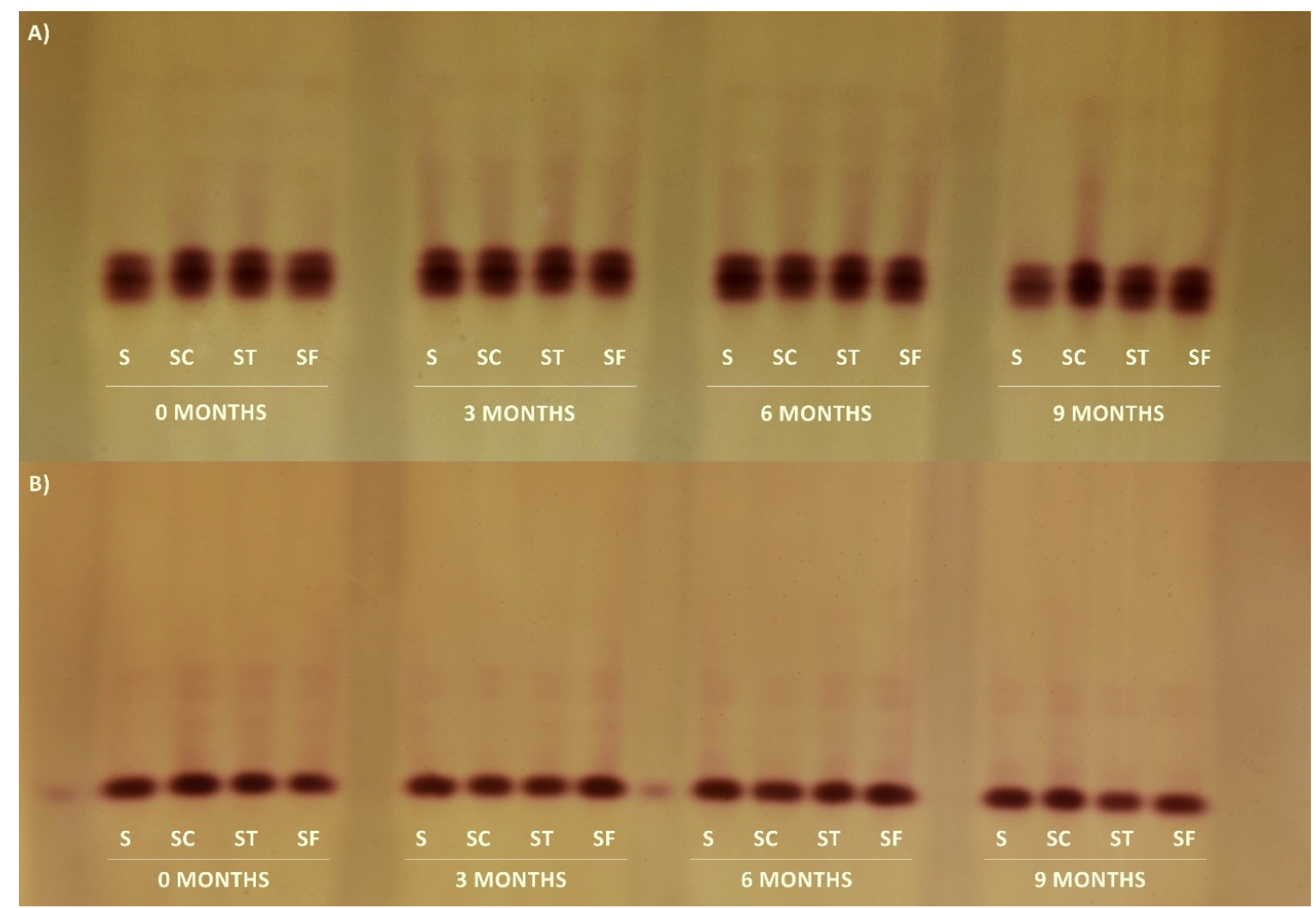

S: standard treatment; SC: standard + clothianidin; ST: standard + thiamethoxam; SF: standard + fipronil.

Figure 2. Esterase expression in seeds of the hybrids 2B647PW (A) and SHS4070 (B) treated with different products and stored for different times (0, 3, 6, and 9 months). 


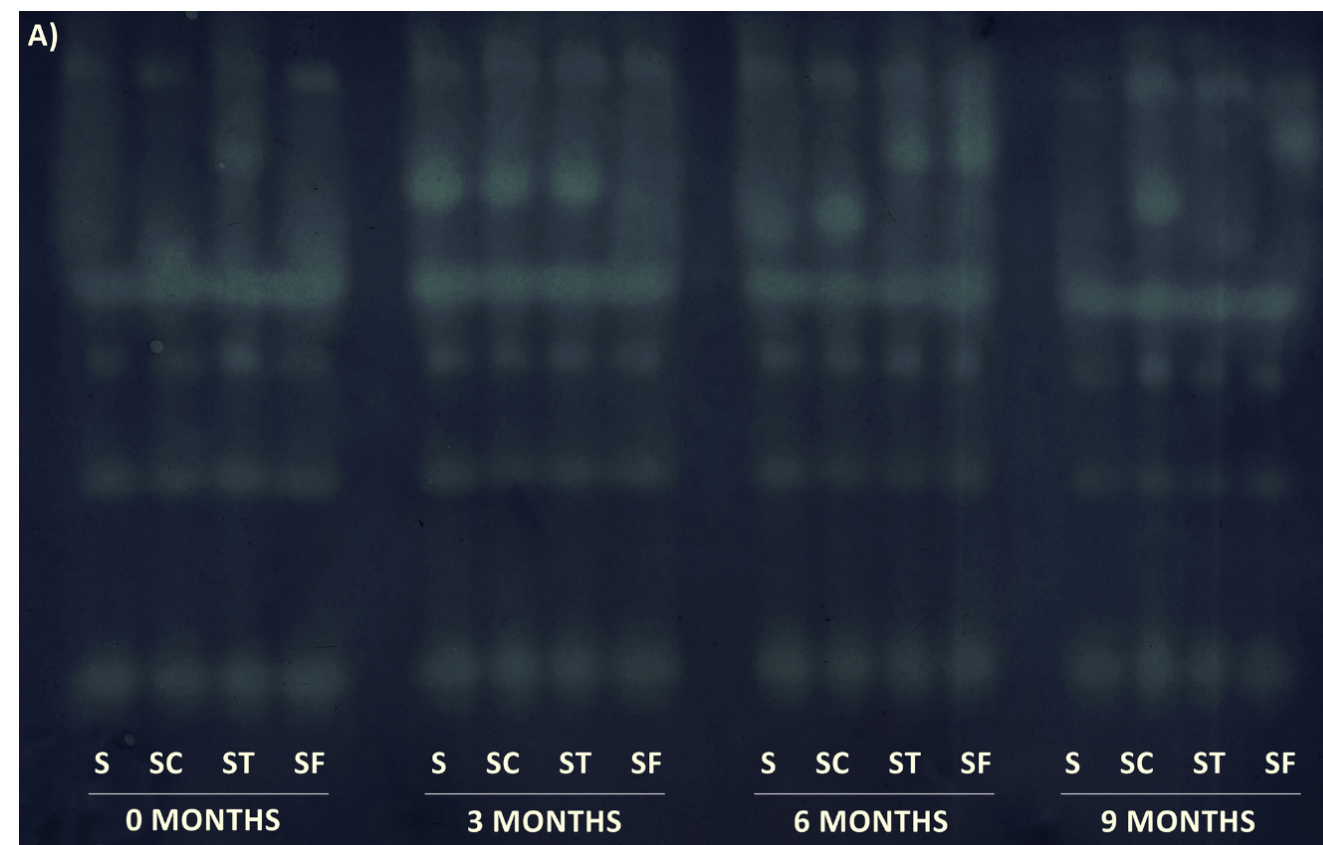

B)

$\frac{S \text { SC ST SF }}{\text { OMONTHS }} \frac{S \text { SC ST SF }}{3 \text { MONTHS }} \frac{S \text { SC ST SF }}{6 \text { MONTHS }} \frac{S \text { SC ST SF }}{9 \text { MONTHS }}$

S: standard treatment; SC: standard + clothianidin; ST: standard + thiamethoxam; SF: standard + fipronil.

Figure 3. Superoxide dismutase expression in seeds of the hybrids 2B647PW (A) and SHS4070 (B) treated with different products and stored for different times ( $0,3,6$, and 9 months). 


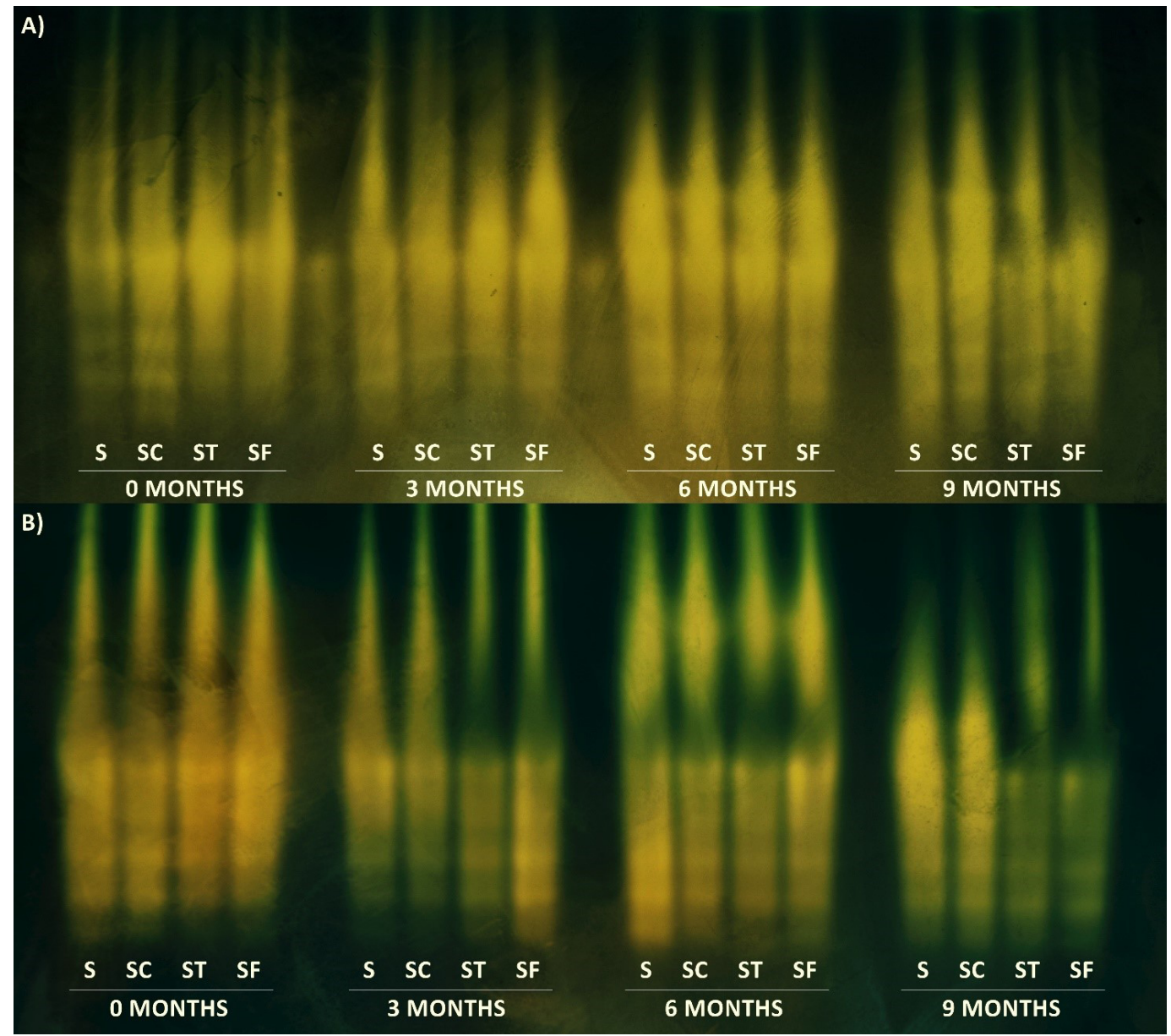

S: standard treatment; SC: standard + clothianidin; ST: standard + thiamethoxam; SF: standard + fipronil.

Figure 4. Catalase expression in seeds of the hybrids 2B647PW (A) and SHS4070 (B) treated with different products and stored for different times (0, 3, 6, and 9 months).

In general, the enzyme alcohol dehydrogenase exhibited a higher intensity of bands in the treatments added of clothianidin, in all storage times investigated (Figure 5). This condition was even more evident in the hybrid SHS4070. A possible explanation for this phenomenon is the greater toxicity of this insecticide compared to the others. It may have accelerated the deterioration, contributing to increasing the respiratory rates of the seeds (Galvão et al., 2014).

Like the enzymes $\alpha$-amylase, superoxide dismutase, and catalase, alcohol dehydrogenase also had its expression decreased by the ninth month of storage in all chemical treatments and hybrid types. As discussed in the previous cases, this reduction can be correlated to the seed physiological deterioration advancement, since the lowering of both synthesis and activity of enzymes are results of this process. Ultimately, the sub-expression of these enzymes is aligned with the results from the physiological quality tests, indicating the possibility of using enzymatic analyzes to study the quality status of corn seeds. 


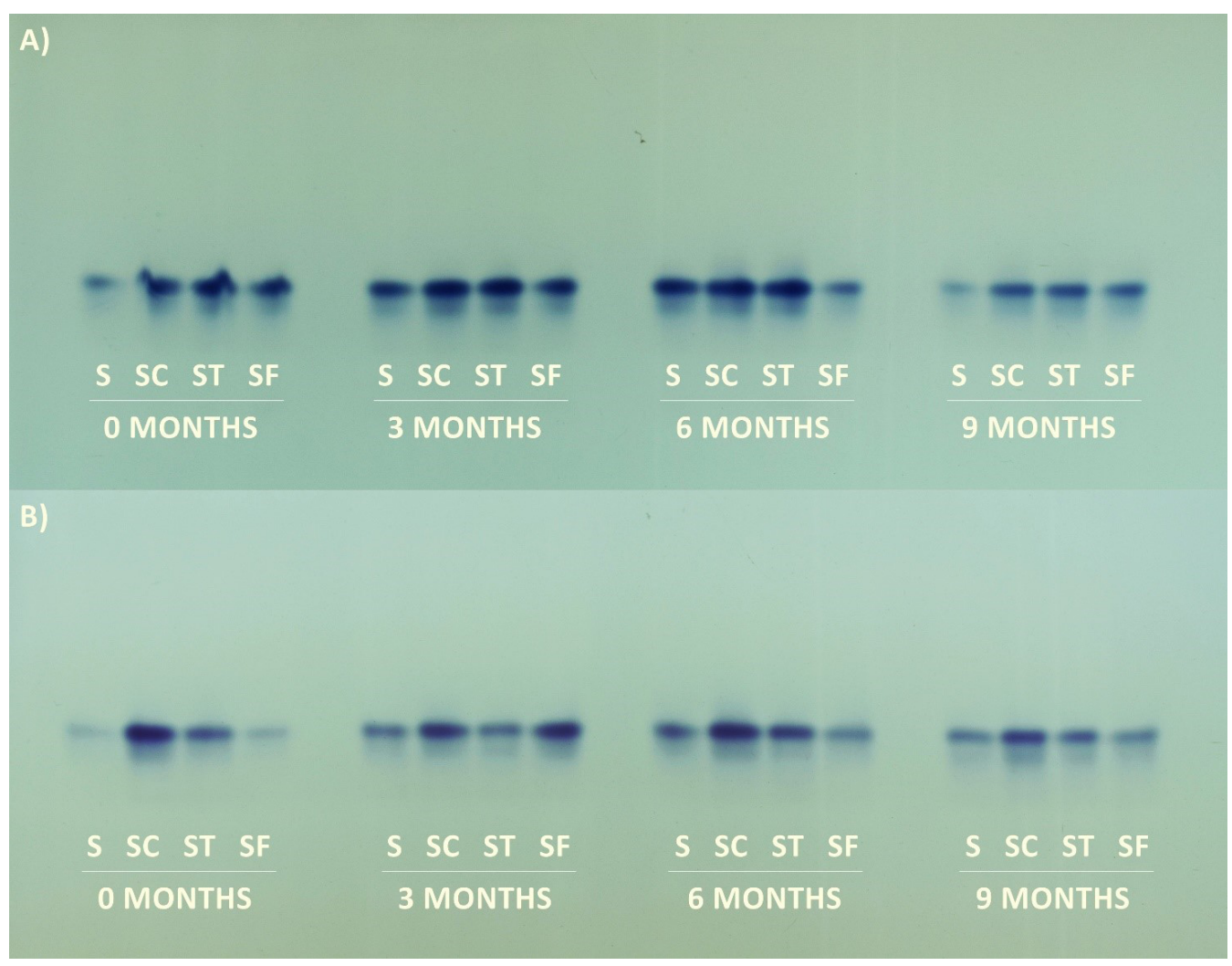

S: standard treatment; SC: standard + clothianidin; ST: standard + thiamethoxam; SF: standard + fipronil.

Figure 5. Alcohol dehydrogenase expression in seeds of the hybrids 2B647PW (A) and SHS4070 (B) treated with different products and stored for different times $(0,3,6$, and 9 months).

\section{CONCLUSIONS}

The quality of corn seeds treated with insecticides and then stored varies according to the chemical, storage time, and hybrid type.

The chemical treatment of seeds is efficient in protecting them against microorganisms during storage.

The insecticides clothianidin, thiamethoxam, and fipronil reduce the physiological quality of seeds of the hybrid 2B647PW after nine months of storage.

Treating corn seeds with the insecticides clothianidin, thiamethoxam, and fipronil reduces the expression of the enzymes $\alpha$-amylase, superoxide dismutase, and catalase after nine months of storage.

The enzymes $\alpha$-amylase, superoxide dismutase, catalase, and alcohol dehydrogenase are good markers of the quality status of hybrid corn seeds during storage.

\section{ACKNOWLEDGMENTS}

The authors would like to express their gratitude to the National Council for Scientific and Technological Development (CNPq), the Coordination for the Improvement of Higher Education Personnel (Capes), and the Research Support Foundation of the state of Minas Gerais (FAPEMIG) for the financial support and the scholarships granted to the researchers. They also thank the Federal University of Lavras (Universidade Federal de Lavras, UFLA) for making available the necessary infrastructure for the research. Finally, to the company Helix Sementes, for donating the material used in this study. 


\section{REFERENCES}

ABREU, L.A.D.S.; CARVALHO, M.L.M.D.; PINTO, C.A.G.; KATAOKA, V.Y.; SILVA, T.T.D.A. Deterioration of sunflower seeds during storage. Journal of Seed Science, v.35, n.2, p.240-247, 2013. http://dx.doi.org/10.1590/S2317-15372013000200015

ALFENAS, A.C. Eletroforese e marcadores bioquímicos em plantas e microrganismos. Viçosa: UFV, 2006. 627p.

ANTONELLO, L.M.; MUNIZ, M.B.; BRAND, S.C.; VIDA, M.D.; GARCIA, D.; RIBEIRO, L.; SANTOS, V. Qualidade de sementes de milho armazenadas em diferentes embalagens. Ciência Rural, v.39, n.7, p.2191-2194, 2009. http://dx.doi.org/10.1590/S010384782009005000157

BALDINI, M.; FERFUIA, C.; PASQUINI, S. Effects of some chemical treatments on standard germination, field emergence and vigour in hybrid maize seeds. Seed Science and Technology, v.46, n.1, p.41-51, 2018. https://doi.org/10.15258/sst.2018.46.1.04

BARROS, A.S.R. Teste de frio. In: KRZYZANOWSKI, F.C.; VIEIRA, R.D.; FRANÇA-NETO, J.B. (Eds.) Vigor de sementes: conceitos e testes. ABRATES, 1999. p.5.1-5.12.

BASHIR, F.; SIDDIQI, T.O.; IQBAL, M. The antioxidative response system in Glycine max (L.) Merr. exposed to Deltamethrin, a synthetic pyrethroid insecticide. Environmental Pollution, v.147, n.1, p.94-100, 2007. https://doi.org/10.1016/j.envpol.2006.08.013

BRASIL. Ministério da Agricultura, Pecuária e Abastecimento. Manual de análise sanitária de sementes. Ministério da Agricultura, Pecuária e Abastecimento. Secretaria de Defesa Agropecuária. Brasília: MAPA/ACS, 2009b. 200p. http://www.agricultura.gov.br/ assuntos/insumos-agropecuarios/insumos-agricolas/sementes-e-mudas/publicacoes-sementes-e-mudas/manual-de-analisesanitaria-de-sementes/view

BRASIL. Ministério da Agricultura Pecuária e Abastecimento. Regras para análise de sementes. Ministério da Agricultura, Pecuária e Abastecimento. Secretaria de Defesa Agropecuária. Brasília: MAPA/ACS, 2009a. 395p. https://www.gov.br/agricultura/pt-br/ assuntos/insumos-agropecuarios/arquivos-publicacoes-insumos/2946_regras_analise_sementes.pdf

BRASIL. Ministério da Agricultura, Pecuária e Abastecimento. Instrução Normativa $n^{\circ} 45$, de 17 de setembro de 2013. Diário Oficial da União, seção 1: 45, 25, 20. https://apps.agr.br/instrucao-normativa-no-45-de-17-de-setembro-de-2013/

CAIXETA, F.; VON PINHO, E.V.D.R.; GUIMARÃES, R.M.; PEREIRA, P.H.A.R.; CATÃO, H.C.R.M.; CLEMENTE, A.D.C.S. Determinação do ponto de colheita na produção de sementes de pimenta malagueta e alterações bioquímicas durante o armazenamento e a germinação. Científica, v.42, n.2, p.187-197, 2014. http://dx.doi.org/10.15361/1984-5529.2014v42n2p187-197

CARVALHO, E.R.; MAVAIEIE, D.P.R; OLIVEIRA, J.A.; CARVALHO, M.V.; VIEIRA, A.R. Alterações isoenzimáticas em sementes de cultivares de soja em diferentes condições de armazenamento. Pesquisa Agropecuária Brasileira, v.49, n.12, p.967-976, 2014. http://dx.doi.org/10.1590/S0100-204X2014001200007

CONAB. Companhia Nacional de Abastecimento. Perspectivas para a Agropecuária - Volume 7 - Safra 2019/2020. https://www. conab.gov.br/perspectivas-para-a-agropecuaria

COSKUN, Y.; KILIC, S.; DURAN, R.E. The effects of the insecticide pyriproxyfen on germination, development and growth responses of maize seedlings. Fresenius Environmental Bulletin, v. 24, p.278-284, 2015. https://www.researchgate.net/publication/272476972_ The_Effects_of_the_Insecticide_Pyriproxyfen_on_Germination_Development_and_Growth_Responses_of_Maize_Seedlings

DEUNER, C.; ROSA, K.C.; MENEGHELlO, G.E.; BORGES, C.T.; ALMEIDA, A.D.S.; BOHN, A. Physiological performance during storage of corn seed treated with insecticides and fungicide. Journal of Seed Science, v.36, n.2, p.204-212, 2014. http://dx.doi. org/10.1590/2317-1545v32n2928

DIAS, M.A.N.; TAYLOR, A.G.; CICERO, S.M. Uptake of systemic seed treatments by maize evaluated with fluorescent tracers. Seed Science and Technology, v.42, p.101-107, 2014. https://doi.org/10.15258/sst.2014.42.1.12

EBONE, L.A.; CAVERZAN, A.; CHAVARRIA, G. Physiologic alterations in orthodox seeds due to deterioration processes. Plant Physiology and Biochemistry, v.145, p.34-42, 2019. https://doi.org/10.1016/j.plaphy.2019.10.028

ESPÍNDOLA, F.; LIMA, P.R.; BORSOI, A.; ECCO, M.; RAMPIM, L. Qualidade fisiológica de sementes de milho tratadas com diferentes inseticidas. Revista Engenharia na Agricultura, v.26, n.4, p.306-312, 2018. https://doi.org/10.13083/reveng.v26i4.943 
FERREIRA, D.F. Sisvar: a computer statistical analysis system. Ciência e Agrotecnologia, v.35, n.6, p.1039-1042, 2011. http://dx.doi. org/10.1590/S1413-70542011000600001

FERREIRA, T.F.; FERREIRA, V.D.F.; OLIVEIRA, J.A.; CARVALHO, M.V.D.; MIGUEL, L.D.S. Isoenzyme activity in maize hybrid seeds harvested with different moisture contents and treated. Journal of Seed Science, v.37, n.2, p.139-146, 2015. http://dx.doi. org/10.1590/2317-1545v37n2147183

GALVÃO, J.C.C.; CONCEIÇÃO, P.M.; ARAÚJO, E.F.; KARSTEN, J.; FINGER, F.L. Alterações fisiológicas e enzimáticas em sementes de milho submetidas a diferentes épocas de colheita e métodos de debulha. Revista Brasileira de Milho e Sorgo, v.13, n.1, p.14-23, 2014. https://doi.org/10.18512/1980-6477/rbms.v13n1p14-23

GANGULI, S.; SENMANDI, S. Effects of ageing on amylase activity and scutellar cell structure during imbibition in wheat seed. Annals of Botany, v.71, n.5, p.411-416, 1993. https://doi.org/10.1006/anbo.1993.1052

HEBERLE, E.; ARAUJO, E.F.; LACERDA-FILHO, A.F.; CECON, P.R.; ARAUJO, R.F.; AMARO, H.G.T.R. Physiological quality and enzyme activity of maize seed during storage. Revista de Ciências Agrárias, v.42, n.3, p.61-70, 2019. http://dx.doi.org/10.19084/rca.17283

HUANG, S.; VAN AKEN, O.; SCHWARZLÄNDER, M.; BELT, K.; MILLAR, A.H. The roles of mitochondrial reactive oxygen species in cellular signaling and stress response in plants. Plant Physiology, v.171, p.1551-1559, 2016. https://doi.org/10.1104/pp.16.00166

KUHNEM-JÚNIOR, P.R.; STUMPF, R.; SPOLTI, P.; DEL PONTE, E.M. Características patogênicas de isolados do complexo Fusarium graminearum e de Fusarium verticillioides em sementes e plântulas de milho. Ciência Rural, v.43, n.4, 2013. http://dx.doi. org/10.1590/S0103-84782013000400004

KUREK, K.; PLITTA-MICHALAK, B.; RATAJCZAK, E. Reactive oxygen species as potential drivers of the seed aging process. Plants, v.8, n.6, p.174, 2019. https://doi.org/10.3390/plants8060174

LOPES, C.A.; CARVALHO, M.L.M.; SANTOS, H.O.; ANDRADE, D.B. Importance of amylases for physiological quality in maize seeds. Biotemas, v.30, n.3, p.1-7, 2017. https://doi.org/10.5007/2175-7925.2017v30n3p1

LORENZETTI, E.R.; RUTZEN, E.R.; NUNES, J.; CREPALLI, M.S.; LIMA, P.H.P.; MALFATO, R.A.; OLIVEIRA, W.C. Influência de inseticidas sobre a germinação e vigor de sementes de milho após armazenamento. Cultivando Saber, v.7, n.1, p.14-23, 2014. https://www. fag.edu.br/revista/cultivando-o-saber/38

MARINI, P.; MORAES, C.L.; LARRÉ, C.F.; LIMA, M.C.; MORAES, D.M.; AMARANTE, L. Indicativo da perda de qualidade de sementes de arroz sob diferentes temperaturas através da atividade enzimática e respiratória. Interciência, v.38. n.1, p.54-59, 2013. https:// www.interciencia.net/wp-content/uploads/2017/12/054-c-MARINI-6.pdf

MENTEN, J.O.M.; MORAES, M.H.D. Tratamento de sementes: histórico, tipos, características e benefícios. Informativo ABRATES, v.20, n.3, p.52-53, 2010.

MENTEN, J.O.M. Prejuízos causados por patógenos associados às sementes. In: MENTEN, J.O.M. (Ed.). Patógenos em sementes: deteç̧ão, danos e controle químico. São Paulo: Ciba Agro, 1995. p.115-136.

MITTLER, R. ROS Are Good. Trends in Plant Science, v.22, n.1, p.11-19, 2017. http://dx.doi.org/10.1016/j.tplants.2016.08.002

OLIVEIRA, G.E.; VON PINHO, R.G.; ANDRADE, T.D.; VON PINHO, E.V.D.R.; SANTOS, C.D.D.; VEIGA, A.D. Physiological quality and amylase enzyme expression in maize seeds. Ciência e Agrotecnologia, v.37, n.1, p.40-48, 2013. http://dx.doi.org/10.1590/S141370542013000100005

PARWEEN, T.; JAN, S.; FATMA, T. Evaluation of oxidative stress in Vigna radiata L. in response to chlorpyrifos. International Journal of Environmental Science and Technology, v.9, n.4, p.605-612, 2012. https://link.springer.com/article/10.1007/s13762-012-0095-x

SHAKIR, S.K.; IRFAN, S.; AKHTAR, B.; UR REHMAN, S.; DAUD, M.K.; TAIMUR, N.; AZIZULLAH, A. Pesticide-induced oxidative stress and antioxidant responses in tomato (Solanum lycopersicum) seedlings. Ecotoxicology, v.27, n.7, p.919-935, 2018. https://doi. org/10.1007/s10646-018-1916-6

SHARMA, I.; BHARDWAJ, R.; PATI, P.K. Stress modulation response of 24-epibrassinolide against imidacloprid in an elite indica rice variety Pusa Basmati-1. Pesticide Biochemistry and Physiology, v.105, n.2, p.144-153, 2013. https://doi.org/10.1016/j. pestbp.2013.01.004 
SHARMA, P.; JHA, A.B.; DUBEY, R.S.; PESSARAKLI, M. Reactive oxygen species, oxidative damage, and antioxidative defense mechanism in plants under stressful conditions. Journal of Botany, v. 2012, p.1-26, 2012. https://doi.org/10.1155/2012/217037

SIES, H.; BERNDT, C.; JONES, D.P. Oxidative stress. Annual Review of Biochemistry, v.86, p.715-48, 2017. https://doi.org/10.1146/ annurev-biochem-061516-045037

SILVA, E.A.A.D.; VON PINHO, É.V.D.R.; VIEIRA, M.D.G.G.C.; CARVALHO, M.L.M.D.; MACHADO, J.D.C. Alterações dos padrões de isoenzimas em sementes de milho infectadas por fungos. Pesquisa Agropecuária Brasileira, v.35, n.9, p.1725-1732, 2000. https:// doi.org/10.1590/S0100-204X2000000900004

SPINOLA, M.C.M.; CÍCERO, S.M.; MELO, M.D. Alterações bioquímicas e fisiológicas em sementes de milho causadas pelo envelhecimento acelerado. Scientia Agricola, v.57, n.2, p.263-270, 2000. http://dx.doi.org/10.1590/S0103-90162000000200011

STEFANELLO, R.; MUNIZ, M.F.B.; NUNES, U.R.; DUTRA, C.B.; SOMAVILLA, I. Physiological and sanitary qualities of maize landrace seeds stored under two conditions. Ciência e Agrotecnologia, v.39, n.4, p.339-347, 2015. https://doi.org/10.1590/S141370542015000400004

TIMÓTEO, T.S.; MARCOS-FILHO, J. Seed performance of different corn genotypes during storage. Journal of Seed Science, v.35, n.2, p.207-215, 2013. http://dx.doi.org/10.1590/S2317-15372013000200010

TONIN, R.F.B; LUCCA-FILHO, O.A.; LABBE, L.M.B.; ROSSETTO, M. Potencial fisiológico de sementes de milho híbrido tratadas com inseticidas e armazenadas em duas condições de ambiente. Scientia Agropecuaria, v.5, n.1, p.7-16, 2014. https://doi.org/10.17268/ sci.agropecu.2014.01.01

VIEIRA, M.G.G.C.; VON PINHO, E.V.R.; SALGADO, K.C.P.C. Técnicas moleculares em sementes. Informe Agropecuário, v.27, n.232, p.88-96, 2006.

YÜCEL, N.C.; HEYBET, E.H.; GOKMEN, O.O. The antioxidant response system in wheat exposed to pesticides and its combinedinduced oxidative damage. Acta Chimica Slovenica, v.65, n.2, p.266-270, 2018. https://doi.org/10.17344/acsi.2017.3586 use, distribution, and reproduction in any medium, provided the original work is properly cited. 